Atıf Bilgisi: Elciyar, K. (2021). Overloading in lockdown: Effects of social, information and communication overloads in covid-19 days. INIF E-Dergi, 6(1), 329 -342.

\title{
OVERLOADING IN LOCKDOWN: EFFECTS OF SOCIAL, INFORMATION AND COMMUNICATION OVERLOADS IN COVID-19 DAYS
}

\author{
Arș. Gör. Dr. Kemal ELCIYYAR* \\ DOI: 10.47107/inifedergi.872896 \\ Araștırma Makalesi*** \\ Başvuru Tarihi: 02.02.2021 \\ Kabul Tarihi: 16.04.2021
}

\begin{abstract}
Many technologies such as Internet, smart tools, social networks have been involved in human life. This increasing prevalence of social networks leaves users facing an overwhelming amount of information, messages, sharing, and social demand. This excess amount is defined as overload. The amount of information constantly flowing in users' networks, social support and communication requests from others can cause fatigue. Overload in social networks can have behavioral and psychological consequences. In this study, a model was used in the context of the SSO (Stress-Strain-Outcome) framework and the changes caused by social, communication and information overloading in an individual's attitudes and behaviors were examined. The research was applied in survey technique and 274 participants' responses were analyzed in this study that examined the experiences of social network users during the Covid-19 process. Outliers in the data are arranged by Mahalanobis distance. Before the use of the scales, factor analyses were performed and their validity was measured. According to the results, only information overload has a significant effect on fatigue. Social and communication overloads do not significantly affect fatigue. Fatigue, on the other hand, has a significant relationship with discontinuous intentions. Users who experience information overloading may experience discontinuous intentions towards social networks. However, it cannot be said that social and communication overloads have caused discontinuous intentions. Although users have high averages in social overload and communication overload, it does not cause fatigue in social networks. Users who have to stay in homes, especially during the quarantine period, can continue to spend time on social networks, despite overloads. In terms of gender, women were found to feel more overloaded on social networks. Women experience more communication, information and social overload. In addition, the fatigue and discontinuous intentions averages are significantly higher.
\end{abstract} Covid-19

Keywords: Information Overload, Social Overload, Communication Overload, Social Networks,

\section{KARANTINADA AŞIRIYÜKLEME: COVID-19 GÜNLERINNDE SOSYAL AĞLARA DEVAM ETMEME NIYETLERI}

$\ddot{O} \mathbf{z}$

İnternet, akıllı araçlar, sosyal ağlar gibi birçok teknoloji son yıllarda insan hayatına dahil olmuştur. Sosyal ağlar bu teknolojik araçların en önemlilerindendir. Sosyal ağların artan bu yaygınlığı, kullanıcıları baş edemeyecekleri, işleyemeyecekleri miktarda bilgi, mesaj, paylaşım ve sosyal taleple karşı karşıya bırakmaktadır. $\mathrm{Bu}$ baş edilemeyecek miktarda akış, aşırıyükleme olarak tanımlanmaktadır. Kullanıcılar ağlarında sürekli akan bilgi miktarından, diğerlerinden gelen sosyal destek, iletişim gibi taleplerden yılgınlık yaşayabilmektedir. Sosyal ağlarda aşırıyüklenme, davranışsal ve psikolojik sonuçlar doğurabilmektedir. Bu çalışmada, Stres-Zorlanma-Çıktı (SSO: Stress-Strain-Outcome) çerçevesi bağlamında bir model kullanılmış ve bireyin tutum ve davranışlarında sosyal, iletişim ve bilgi aşırı yüklenmesinden kaynaklanan değişiklikler incelenmiştir. Araştırma tarama modelinde uygulanmıştır ve Covid-19 sürecinde sosyal ağ kullanıcılarının deneyimlerini inceleyen bu çalışmada 274 katılımcının cevabı analiz edilmiştir. Verilerdeki aykırı değerler, mahalanobis uzaklığı ile düzenlenmiştir. Veriler değerlendirilmeden önce faktör analizleri yapılmış ve geçerliliği ölçülmüştür. Elde edilen sonuçlara göre, sadece bilgi aşırıyüklenmesinin ağ yılgınlığı üzerinde anlamlı bir etkisi vardır. Sosyal ve iletişim aşırıyüklemeleri ağ yılgınlığını anlamlı bir şekilde

\footnotetext{
*Anadolu Üniversitesi, İletişim Bilimleri Fakültesi, İletişim Tasarımı ve Yönetimi Bölümü, E-mail: kemalelciyar@anadolu.edu.tr, ORCID ID: 0000-0002-7820-2978

** Yazar / yazarlar, makalede araştırma ve yayın etiğine uyulduğuna ve kullanılan fikir ve sanat eserleri için telif hakları düzenlemelerine riayet edildiğine yönelik beyanda bulunmuştur.
} 
etkilememektedir. A $\breve{g}$ yılgınlığı, diğer taraftan, devam etmeme niyeti ile anlamlı bir ilişkiye sahiptir. Artan ağ yılgınlığı, devam etmeme niyetini artırmaktadır. Bilgi aşırıyüklemesi yaşayan kullanıcılar, sosyal ağlara yönelik devam etmeme niyeti yaşayabilmektedir. Bununla birlikte, sosyal ve iletişim aşırıyüklemelerinin devam etmeme niyetine yol açmadığı görülmüştür. Kullanıcılar her ne kadar sosyal aşırıyükleme ve iletişim aşırıyüklemesinde yüksek ortalamalara sahip olsalar da sosyal ağlara yönelik yılgınlığa neden olmamaktadır. Özellikle karantina döneminde evlerde kalmak zorunda olan kullanıcıların yapacakları şeylerin sınırlı olması, aşırıyüklemelere rağmen sosyal ağlarda vakit geçirmeye devam edebilmektedir. Cinsiyet açısından ise, kadınların sosyal ağlarda daha fazla aşırıyükleme deneyimlediği tespit edilmiştir. Kadınlar daha fazla iletişim, bilgi ve sosyal aşırıyükleme yaşamaktadır. Ayrıca ağ yılgınlığı ve devam etmeme niyeti ortalamaları anlamlı şekilde daha yüksektir.

\section{Anahtar Kelimeler: Bilgi Aşırlyüklemesi, Sosyal Aşırıyükleme, Iletişim Aşırlyüklemesi, Sosyal Ağlar, Covid-19}

\section{Introduction}

In recent years, many new technologies have been involved in human life. Among these technologies are smartphones, Internet, smart tools and social networks (SNS) that are central to people's lives (Farhoomand and Drury, 2002; Hargittai et al., 2012). SNS have increased in popularity, especially with the development of mobile technologies. SNS are an important part of these contacts and the internet experience. Along with SNS, users have had millions of connections. Users have become accessible to each other, and the boundaries of time and space between them have disappeared (Koroleva et al., 2010, p. 1; Larose et al., 2014, p. 59; Maier et al., 2013, p. 2). The survival of these networks depends largely on active users. Social network providers need to prevent users from experiencing fatigue in order not to lose their users (Laumer et al., Wirth, 2015, p. 1). According to the results of a Pew study (Rainie et al., 2013) users are leaving Facebook due to rumors, unnecessary messages, system updates, an unrelated and intense flow of information.

The rapid spread of these technologies has left individuals with unlimited content and information (Nematzadeh et al., 2019). Members of Generation Z have different experiences in accessing information. Opportunities such as smartphones and internet technologies allowed these people to access information quickly and easily. Even information has now reached an insurmountable amount (Gouws ve Tarp, 2016). A lot of information, such as people's lives, news, various rumors, events, is shared on SNS, and other users are also expected to show interest in such flows. But overload occurs if the flow exceeds the capacity of users (Cherubini et al., 2010, p. 985; Koroleva et al., 2010, p. 1). Overloads are the cause of the negative consequences of technologies that individuals experience (Shin and Shin, 2016). New information and communication technologies aimed at providing quick and easy access to information and other contents are responsible for a large part of the overload effect (Bawden and Robinson, 2009, p. 5; Shin and Shin, 2016). The feeling of overloading can often end in loss of control over the situation and depression (Bawden and Robinson, 2009; Song et al., 2017). Effects such as time loss, decision-making delays, distraction, stress are also observed (Waddington, 1997). Elements that exceed the individual's capacity can also be information, as well as social factors (Saegert, 1973). Therefore, there is a need to investigate the effects of the flow, notifications, shares that people are exposed to. Some other concepts used in overload research are technology overload (Karr-Wisniewski and Lu, 2010), stress overload (Amirkhan, 2011), connection overload (Larose et al., 2014), connection overload (Larose et al., 2014). In this study, social, communication and information overloads were discussed in the context of the SSO framework. Especially in the Covid-19 period, it is aimed to reveal how SNS were used and what the effects were. Young users who have to be at home during lockdown periods increase their use of SNS for many purposes, such as maintaining connections with them due to their distance from their friends, tracking 
information about the epidemic and other issues, and sharing their experience in the epidemic process (Pérez-Escoda et al., 2020). The study of the effects of increased use on users' perceptions of overloading will contribute to the understanding of pandemic experiences and the use of SNS in extraordinary situations.

\section{SSO Framework}

Due to the transformations created by information and communication technologies, intensive information and messages that a person is constantly exposed to, both in private and in business, can create stress (Lee et al., 2016, p.775). In the study, stress-strain-outcome (SSO) framework was applied when addressing overload in the context of SNS. When the stress process is examined in the framework of SSO, the stressor acts on the user's strain, resulting in a behavioral output (Koeske and Koeske, 1993, p. 110). Stress is an environmental stimuli and perceived by the actor as potentially disruptive. Strain has disruptive impacts on actor's physiology, and emotion and outcomes are behavioral or psychological consequences of stress and strain (Fu et al., 2020; Koeske and Koeske, 1993; Nawaz et al., 2018). In the context of SNS, overloading is a stressor that is effective in an individual's attitudes. Examples of attitudes are the feeling of regret and fatigue towards SNS. Stresses, on the other hand, will cause the individual to quit social media or not want to continue (Fu et al., 2020, p. 4; S. Lee et al., 2016; Ravindran et al., 2014; Zhang et al., 2016). In this study, information, communication and social overload were considered as types of overload, i.e. stressors. Strain consists of SNS fatigue and affects not continuing behavior as a result.

\subsection{Information Overload}

Information overload, which emphasizes the more quantitative aspect of information (Meyer, 1998, p. 200) and occurs when individuals encounter an amount of information that exceeds their capacity, more than they can process (Farhoomand and Drury, 2002, p. 127), is not a new phenomenon. Since knowledge becomes important to human activities, there is a possibility of overloading (Allen and Wilson, 2003). In fairly ancient times, there were also studies that argue that people feel overloaded with information (Blair, 2011, p. 1). Information and communication technologies are accelerating the increase in information materials today (Hoq, 2016, p. 52). Information and communication technologies provide opportunities to access large amounts of information and overcome time and place constraints (Misra and Stokols, 2012, p. 738). Overloading has been possible for all segments of society (Roetzel, 2019, p. 480). It is believed that with the advancement of technology, information overloading will also increase (Benselin and Ragsdell, 2015; Levy, 2009). Distortions in the quality and intensity of information also affect satisfaction with the SNS. Some criteria can be considered when evaluating this quality (Xu et al., 2014, p. 243): "timeliness, reliability, format and amount of information".

Individuals exposed to flow from multiple sources (Misra and Stokols, 2012), may feel overloaded and overwhelmed if they do not have the necessary abilities and competencies (Benselin and Ragsdell, 2015). It may lose control, become confused, and regret his decisions (Zhang et al., 2016, p. 907). Especially in SNS, users who encounter a lot of information every day experience similar processes. Users move away from the platform, especially when the information is irrelevant and disturbing (Zhang et al., 2016). The expansion of SNS also increases the amount of information exposed ((Ragu-Nathan et al., 2008, p. 421). This increasing amount of information can also lead to fatigue in users towards SNS.

H1. Information overload positively impacts regret. 


\subsection{Social Overload}

Considering the concept of overloading in a sociological context, crowds come to mind. "Individuals' interaction capacity or ability to process relevant incoming social stimuli tenants" will result in social overload (McCarthy and Saegert, 1978, p. 253). According to this view, as the "crowd" increases, individuals spend more effort to maintain their relationships and improve their social ties. Because in crowded environments, interactions that individuals can experience with others occur more often (Baum and Valins, 1977). This, in turn, leads to mental and psychological problems. Individuals experience greater difficulty in regulating the qualities, frequency, or duration of their social contact in such environments. The intensity of the interactions he or she experiences with his or her social environment can have negative consequences on the individual (McCarthy and Saegert, 1978), while the individual may avoid interactions. For example, a crowd inside the house can drive it away from the house. From this point of view, SNS are also areas that host crowds and are similar to our neighborly and friendly relationships in our daily lives. Similar effects may arise from these interactions (Shokouhyar et al., 2018, p. 347).

In SNS, individuals can support each other, reduce their loneliness and boredom, and have fun. Such benefits increase the information that users are exposed to, the intensity of communication, and the need to obtain social support and provide it to others. Sometimes requests and interactions from other users can lead to more effort and exposure to more communication. This excessive social demand leads to the need for energy and time (A. R. Lee et al., 2016). When these requirements exceed an individual's capacities, the user's satisfaction also decreases (Zhang et al., 2016).

Increased connections and notifications will reveal social overload in the individual (Maier et al., 2012; Ravindran et al., 2014). Social overload defines "stress that users feel because they respond to too many requests through the SNS for social support, address friends' problems through SNS posts, and pay attention to matters important to friends" (Tarafdar et al., 2020, p. 99). ANS users feel pressure from demands from others, and fatigue arises (Cao et al., 2019). Therefore, users may feel unwilling to network.

H2. Social overload positively impacts regret.

\subsection{Communication Overload}

It is possible to summarize communication overload as an individual's exposure to more messages than they can handle in the communication process (Chung and Goldhaber, 1991 cited in Cho et al., 2011). Karr-Wisniewski and Lu (2010, p. 1063) argue that communication overload occurs when "a third party solicits the attention of the knowledge worker through such means as email, instant messaging, or mobile devices that cause excessive interruptions". Communication overload makes it difficult for users to refocus and may cause them not to continue their work (Cho et al., 2011). This difficulty in refocusing causes communication overload to make individuals feel tired and can increase stress (A. R. Lee et al., 2016). Users who cannot cope with the situation may feel overwhelmed.

H3. Communication overload positively impacts regret.

\subsection{Fatigue and Discontinuous Intention}

The introduction of SNS into lives has led to an uncontrollable flow of information and the need for communication and social support. In addition to the benefits that can be considered, excessive use of SNS also has undesirable consequences. One of them is SNS 
fatigue, which can be considered as feeling tired due to the use of the SNS (A. R. Lee et al., 2016). One of the most important reasons why users experience fatigue for information systems such as SNS and then do not want to use these systems is overload (Fu et al., 2020 , p. 2). It may be particularly fatigue when the user's online social connections demand a lot of social support and the excess of information is perceived (Maier et al., 2015, p.1). As a result of fatigue, it can reduce their use of SNS and their activity here (Ravindran et al., 2014, p. 2306).

H4. Fatigue positively impacts discontinuous intention.

\section{Methodology}

\subsection{Sample and data collection}

The participants of this study are university students located in Eskişehir/Turkey. During periods when epidemic measures and curfew were partially reduced, data were collected by conducting a face-to-face survey with participants. Necessary health measures were also taken during the data collection process. Participants were asked if they used a social network before the survey was conducted, and no data was collected from those who do not. The social network that was asked for the opinion of the participants in the study was Instagram, which has recently been more widely used by young people. 297 data were collected by conducting face-to-face surveys from university students who are active users of SNS and are the majority of users of these platforms. However, 274 usable data were obtained when outliers data were extracted by calculating Mahalanobis distance.

Table 1. Demographics

\begin{tabular}{|c|c|c|c|}
\hline Variables & & $\mathbf{n}$ & $\%$ \\
\hline \multirow[t]{2}{*}{ Gender } & Male & 146 & 53,3 \\
\hline & Female & 128 & 46,7 \\
\hline \multirow[t]{4}{*}{ Followers } & $0-100$ & 22 & 8,0 \\
\hline & $100-300$ & 57 & 20,8 \\
\hline & $300-500$ & 97 & 35,4 \\
\hline & $500+$ & 98 & 35,8 \\
\hline \multirow[t]{4}{*}{ Sharing frequency } & Every day & 27 & 9,9 \\
\hline & Several times a week & 77 & 28,1 \\
\hline & Several times a month & 102 & 37,2 \\
\hline & Several times a year & 68 & 24,8 \\
\hline \multirow[t]{3}{*}{ SNS usage } & 0-1 hour & 42 & 15,3 \\
\hline & 1-3 hours & 121 & 44,2 \\
\hline & $3+$ hours & 111 & 40,5 \\
\hline \multirow[t]{4}{*}{ Usage purpose } & Meeting new people & 16 & 5,8 \\
\hline & Having fun & 90 & 32,8 \\
\hline & Self-expression & 21 & 7,7 \\
\hline & Time wasting & 147 & 53,6 \\
\hline
\end{tabular}

Of the 274 participants, $146(53.3 \%)$ were male and $128(46.7 \%)$ were female. 42 participants (15.3\%) spend 0-1 hours, 121 participants (44.2\%) spend 1-3 hours, and 111 participants $(40.5 \%)$ spend hours on SNS. 22 participants stated that they had 0-100 (8\%) friends/followers, 57 participants had 100-300 (20.8\%) friends/followers, 97 participants had 300-500 (35.4\%) friends/followers, and 98 participants had 500+ friends/followers. To the question of why they spend time on SNS, 16 (5.8\%) of respondents answered meeting new people, 90 (32.8\%) having fun, 21 (7.7\%) expressing themselves, and 147 (53.6\%) spending time. 


\subsection{Measures}

To ensure validity, measures adapted from previous researches. Information overload measure is adapted from the work of Karr-Wisniewski and Lu (2010). Social overload measure is taken from Maier et al.'s (2014) research. Communication overload, regret and discontinuous intention measures adapted from the study of Cao and Sun (2018). Social network fatigue measure retrieved from Zhang et al.'s (2016) research. All items used are strongly disagree (1) to strongly agree (5) ranging five-point Likert scale. Items were translated into Turkish, evaluated by language experts, translated back into English and analyzed. After these reviews, a pilot study and minor corrections were made and the scale was given its final version. Also, questionnaires were collected in a crosssectional survey and due to that a common method bias problem may exist. Common method bias calculated by Harman's single factor test (Podsakoff et al., 2003). The single factor accounts for $27.7 \%$ of the total variation. This result shows that the common method bias was not likely to have been a significant problem. For multicollinearity possibilities, VIF values were also looked at and found to be below 10 .

\section{Results}

\subsection{Measurement Model}

The construct validity of the scales was calculated by exploratory factor analysis. Principle component analysis and varimax rotation were implemented when performing EFA. But five factors were obtained from the research model created as six constructs. Four items were removed from the model, and regret and discontinuous intention constructs were collected under a single factor. Five factors have an Eigen value of 1.17 and explain $67.6 \%$ of the variance. All elements are strongly loaded into the corresponding factors. The EFA factor loadings of all items are greater than 0.6. This also shows a good convergent and discriminant validity. All Cronbach's alpha values over 0,70. It shows that the reliability of this scale is high (Hair et al., 1998).

Convergent and discriminant validities were measured by confirmation factor analysis. The obtained fit indices: $\mathrm{x}^{2}(187) ; 538,331 ; \mathrm{p}<0.001 ; \mathrm{x}^{2} / \mathrm{df} 2,879$; GFI 0.836; IFI 0.887; RMSEA 0.083; NFI 0.837; TLI 0.873; CFI 0.886 and indicated that the hypothesized four factor model was a reasonable fit (Doll et al., 1994). Convergent validity and reliability of the model were measured with average variation extracted (AVE) and composite reliability (CR) values. CR values are above 0.70 , as shown in Table 2 . All AVE values are also above 0.40. An adequate model has been obtained when two values are considered together (Fornell and Larcker, 1981).

Table 2. Factor loadings, validities and C. Alpha values

\begin{tabular}{|c|c|c|c|c|c|}
\hline Factors & Items & Mean & Loadings & t-value & $\begin{array}{l}\text { Cronbach } \\
\text { Alpha }\end{array}$ \\
\hline Social Ov. & SOC1 & 3.12 & 0,64 & & 0.866 \\
\hline $\mathrm{CR}=\quad \mathbf{0 , 8 6 0}$ & SOC2 & 3.11 & 0,68 & 11.99 & \\
\hline \multirow{3}{*}{$\mathrm{AVE}=0,696$} & SOC3 & 3.75 & 0,71 & 9.92 & \\
\hline & SOC4 & 3.56 & 0,92 & 11.44 & \\
\hline & SOC5 & 3.59 & 0,75 & 10.36 & \\
\hline Fatigue & FAT1 & 3.63 & 0.69 & & 0.842 \\
\hline $\mathrm{CR}=0,846$ & FAT2 & 3.31 & 0.91 & 12.22 & \\
\hline \multirow[t]{2}{*}{$A V E=0,585$} & FAT3 & 3.06 & 0.80 & 11.65 & \\
\hline & FAT5 & 3.47 & 0.63 & 9.37 & \\
\hline
\end{tabular}




\begin{tabular}{llllll}
\hline Communication Ov. & COM1 & 3.54 & 0.62 & & 0.734 \\
\hline CR= 0,742 & COM3 & 2.99 & 0.76 & 7.85 & \\
\hline $\mathbf{A V E}=\mathbf{0 , 4 2 0}$ & COM4 & 3.43 & 0.59 & 7.10 & \\
\hline & COM5 & 3.02 & 0.61 & 7.29 & \\
\hline Information Ov. & & & & & 0.708 \\
\hline $\mathbf{C R}=\mathbf{0 , 7 3 9}$ & INF1 & 2.75 & 0.73 & & \\
\hline $\mathbf{A V E}=\mathbf{0 , 5 0 3}$ & INF2 & 2.83 & 0.89 & 6.61 & \\
\hline & INF3 & 3.18 & 0.43 & 6.39 & \\
\hline Discontinuous Intention & DI 1 & 3.18 & 0.90 & & 0.914 \\
\hline $\mathbf{C R}=\mathbf{0 , 9 1 8}$ & DI2 & 3.23 & 0.98 & 29.07 & \\
\hline $\mathbf{A V E}=\mathbf{0 , 8 7 5}$ & DI3 & 3.24 & 0.95 & 26.52 & \\
\hline & REG1 & 2.81 & 0.57 & 10.63 & \\
\hline & REG2 & 3.34 & 0.71 & 14.66 & \\
\hline
\end{tabular}

\subsection{Structural Model}

The Amos program and the structural equality modeling technique were used to test the research framework. Obtained fit indices: $\mathrm{x}^{2}(180) ; 347,668 ; \mathrm{p}<0.001 ; \mathrm{x}^{2} / \mathrm{df} 1,931$; GFI 0.895; IFI 0.946; RMSEA 0.058; NFI 0.895; TLI 0.937; CFI 0.946. Fit indices of the structural model are acceptable. As seen in Table 3, Hypothesis 1 deals with the relationship between information overload and SNS fatigue and was supported ( $\beta=0.446$, $\mathrm{p}<0.01)$. Hypothesis 2 examines the relationship between social overload and regret and was not supported $(\beta=-0.019, p>0.05)$. Hypothesis 3 measures the relationship between communication overload and regret and was not supported $(\beta=0.130, p>0.05)$. Hypothesis 4 examines the relationship between fatigue and discontinuous intention and was supported $(\beta=0.761, p<0.01)$. Furthermore $26 \%$ of SNS fatigue variance is explained by three types of overloading and $30 \%$ of discontinuous intention variance is explained by other antecedents.

In the stressor, strain, and outcome approach, since strain has a mediating role in the relationship between stressor and outcome, mediating analysis has also been performed (Koeske and Koeske, 1993). Fatigue, which is a strain, only has a significant mediating role in the relationship between information overload and discontinuous intention. There is no significant mediating role in the relationship between social overload and communication overload and discontinuous intention.

Table 3. Path results

\begin{tabular}{lccccc}
\hline Hypothesis & Path & Std. coefficient & $\mathbf{p}$ & t-values & Result \\
\hline H1 & Inf Ov > Fatigue & 0.447 & 0.000 & 5,505 & S \\
\hline H2 & Soc Ov > Fatigue & -0.013 & 0,851 & $-0,188$ & NS \\
\hline H3 & Com Ov > Fatigue & 0.130 & 0.191 & 1,307 & NS \\
\hline H4 & Fatigue > Dis. Intention & 0.767 & 0.000 & 8,017 & S \\
& Indirect effects & $\begin{array}{c}\text { Std. } \\
\text { coefficient }\end{array}$ & p & Result \\
\hline & Inf Ov > Fatigue > Dis. Intention & 0,252 & 0,001 & S \\
\hline & Soc Ov > Fatigue > Dis. Intention & $-0,007$ & 0,839 & NS \\
\hline & Com Ov > Fatigue > Dis. Intention & 0,063 & 0,265 & NS \\
\hline
\end{tabular}

S=Significant

NS=Non-significant

\subsection{Gender Differences}

Finally, the relationship between gender and other variables was measured by t-test. Table 4 shows that women's averages are significantly higher across all constructs. Women have experienced more overloading than men in recent periods, and the fatigue they feel from 
SNS and their discontinuous intentions are also higher. In general, quite high averages are observed in all constructs.

\begin{tabular}{|c|c|c|c|c|c|c|c|c|}
\hline \multirow[t]{2}{*}{ Measure } & \multirow{2}{*}{$\begin{array}{l}\text { Overall } \\
\text { M (SD) }\end{array}$} & \multicolumn{2}{|c|}{ Gender } & \multirow[t]{2}{*}{$\mathbf{t}$} & \multirow[t]{2}{*}{ df } & \multirow[t]{2}{*}{$\mathbf{p}$} & \multicolumn{2}{|c|}{$\% 95$ CI } \\
\hline & & $\begin{array}{l}\text { Male } \\
\text { (SD) }\end{array}$ & $\begin{array}{l}\text { Female } \\
\text { (SD) }\end{array}$ & & & & Lower & Upper \\
\hline $\begin{array}{l}\text { Information } \\
\text { overload }\end{array}$ & $2,92(0,99)$ & $\begin{array}{l}2,78 \\
(0,99)\end{array}$ & $3,10(0,97)$ & $-2,681$ & 272 & 0,008 & $-0,55$ & -085 \\
\hline $\begin{array}{l}\text { Communication } \\
\text { overload }\end{array}$ & $3,24(0,95)$ & $\begin{array}{l}3,03 \\
(0,95)\end{array}$ & $3,50(0,88)$ & $-4,219$ & 272 & 0,000 & $-0,69$ & $-0,25$ \\
\hline Social overload & $\begin{array}{l}3,42 \\
(0,980)\end{array}$ & $\begin{array}{l}3,22 \\
(1,02)\end{array}$ & $3,66(0,88)$ & $-3,801$ & 272 & 0,000 & $-0,66$ & $-0,21$ \\
\hline Fatigue & $3,37(1,10)$ & $\begin{array}{l}3,15 \\
(1,03)\end{array}$ & $3,62(1,12)$ & $-3,575$ & 272 & 0,000 & $-0,72$ & $-0,20$ \\
\hline $\begin{array}{l}\text { Discontinuous } \\
\text { intention }\end{array}$ & $3,16(1,18)$ & $\begin{array}{l}2,97 \\
(1,12)\end{array}$ & $3,38(1,22)$ & $-2,798$ & 272 & 0,005 & $-0,67$ & $-0,12$ \\
\hline
\end{tabular}

\section{Discussion}

The aim of this research is to examine the overloadings and discontinuous intentions of young people towards SNS who are forced to stay in their homes during Covid-19 days, especially during periods of curfew restrictions, based on the stress-strainoutcome framework. Three types of overloading are examined for SNS; social overload, information overload, communication overload. First, as opposed to theoretical prediction (Bright, et al., 2015; Cao et al., 2019; Laumer et al., 2015; Nawaz et al., 2018) social overload does not affect fatigue (Shokouhyar et al., 2018). Likewise, communication overload has no significant effect (S. Lee et al., 2016). But information overload as expected has a positive effect on fatigue (Fu et al., 2020; Shokouhyar et al., 2018; Zhang et al., 2016). It is only information overload that has a significant impact on SNS fatigue. It has been highlighted in previous research that strains can lead to negative outcomes, discontinuous intention to continue using SNS. Fatigue, which can be caused by overloads, has a significant association with discontinuous intention to use SNS. Individuals who feel fatigue are more inclined to leave SNS. However, the feelings of fatigue experienced by individuals can vary, even if they occur in the face of the same situation (Ravindran et al., 2014, p. 2307). In other words, some users may experience fatigue in SNS due to their friends and the intensity they create; others may cope with the same subjective situation.

A lot of information has been circulating on SNS since Covid-19 began spreading. Among the information circulating are even opinions arguing that the pandemic was a conspiracy (Allington et al., 2020). Quick and easy dissemination of information causes false and misleading information to reach SNS users in the Covid-19 process (Goel and Gupta, 2020). Sometimes exposure to unnecessary information and misinformation (Laato et al., 2020) can also cause information overload (Rathore and Farooq, 2020), and fatigue towards SNS can occur. Sometimes information itself can also cause stress and anxiety, causing a person to leave SNS.

During the Covid-19 process, many countries ask their citizens to stay in their homes and pay attention to social distance. Users who are closed to their homes receive more messages and notifications from others, and communication can become excessive. Naturally, there has also been a change in the interactions that people experience with each other. People communicate with each other remotely, via SNS or etc. (Nabity-Grover, Cheung, and Thatcher, 2020). When looking at the responses of participants, having fun and time wasting were also found to be the most common motive in the use of SNS. For 
individuals who have been "imprisoned" in homes, there are few alternatives other than SNS to have fun and spend time. Therefore, although perceptions of social overload and communication overload are high, individuals may not feel fatigue towards SNS. During this period, the use of SNS increased by $61 \%$. People spent more time on SNS during their stay at home (Holmes, 2020). As long as they stayed at home, they shared their home life with others, and uploaded their experiences with their family. In Covid-19 days, people are more in solidarity because there is a common problem. Celebrities give moral support by giving concerts on SNS, users can help more among themselves. In this context, it is seen that there is an intense communication and social flow. Therefore, it is understandable that participants give high scores for overloads. People meet their socialization, communication and information needs through SNS. Healthy communication and socialization with others can reduce the loneliness, fear, and boredom that individuals experience.

\section{Implications}

There are some theoretical implications of this research. In general, the research dealt with a combination of three types of overload. Some new findings have been obtained. In the context of technostress and SSO framework, the negative aspects of SNS have been emphasized. It is not focused on stages such as adaptation and use of information systems, but on the process by which users leave information systems (Cao and Sun, 2018). It also provides an empirical validation contribution to the relation of social, communication and information overloads. In particular, SNS experiences of young users who had to stay in their homes during Covid-19 days and whose face-to-face interaction decreased due to social distance were tried to be revealed by this research. The research also contributes to the SSO framework and offers new insights. Information, communication and social overloads were examined and participants' perceptions were discussed. It has also been found that women are more affected by overloads by addressing gender differences. Finally, how SNS users are affected by their experience of overloads was examined. According to results only information overload has a significant effect on fatigue. Intense flow of information about Covid-19, sometimes encountering false information, can cause participants to experience information overload. But users who have little to do in their homes may have continued to socialize and communicate. The negative emotions that developed with fatigue, on the other hand, strengthened the participants' discontinuous intention. In this context, research has also sought to reveal psychological motives to explain the discontinuous intention of information systems. It contributes to subsequent research by examining the psychological process associated with the use of SNS, especially during epidemic days, and the reasons why networks do not continue. It contributes to subsequent research by examining the psychological process and causes of discontinuous intention related to the use of SNS, especially during epidemic days.

The research has some practical implications. It primarily provides SNS developers and providers with perspectives on what to look out for if they don't want to lose their users. In particular, in order to prevent information overload, the dissemination of false information needs to be controlled. There are insights for decision makers and families who want to manage the flow of information and are curious about how young people spend time on SNS and their psychological effects.

This empirical research has applied to 274 participants and examined information, communication and social overloads and discontinuous intention to SNS. According to the results, information overload has an effect on fatigue; information and communication overload has no significant effect. Fatigue, on the other hand, has a positive impact on 
discontinuous intention. In addition, women have a higher perception of overloading than men. Research findings contribute to SNS use and its psychological effects in Covid-19 days.

\section{References}

Allen, D. and Wilson, T. D. (2003). Information overload: Context and causes. The New Review of Information Behaviour Research, 4(1), 31-44.

Allington, D., Duffy, B., Wessely, S., Dhavan, N. and Rubin, J. (2020). Health-protective behaviour, social media usage, and conspiracy belief during the COVID-19 public health emergency. Psychological Medicine, 1-15.

Amirkhan, J. (2011). Stress overload: A new approach to the assessment of stress. American Journal of Community Psychology, 49, 55-71.

Baum, A. and Valins, S. (1977). Architecture and social behavior: Psychological study of social density. New York: Wiley.

Bawden, D. and Robinson, L. (2009). The dark side of information: Overload, anxiety and other paradoxes and pathologies. Journal of Information Science, 35(2), 180-191.

Benselin, J. C. and Ragsdell, G. (2015). Information overload: The differences that age makes. Journal of Librarianship and Information Science, 48(3), 284-297.

Blair, A. (2011). Information overloadings 2,300-year-old history. Harvard Business Review, 3 .

Bright, L. F., Kleiser, S. B. and Grau, S. L. (2015). Too much Facebook? An exploratory examination of social media fatigue. Computers in Human Behavior, 44, 148-155.

Cao, X., Khan, A., Ali, A. and Khan, N. (2019). Consequences of cyberbullying and social overload while using SNSs: A study of users' discontinuous usage behavior in SNSs. Information Systems Frontiers, 22, 1343-1356.

Cao, X. and Sun, J. (2018). Exploring the effect of overload on the discontinuous intention of social media users: An S-O-R perspective. Computers in Human Behavior, 81, $10-18$.

Cherubini, M., Gutierrez, A., De Oliveira, R. and Oliver, N. (2010, April). Social tagging revamped: supporting the users' need of self-promotion through persuasive techniques. Proceedings of the SIGCHI Conference on Human Factors in Computing Systems. (p. 985-994). ACM.

Cho, J., Ramgolam, D. I., Schaefer, K. M. and Sandlin, A. N. (2011). The rate and delay in overload: An investigation of communication overload and channel synchronicity on identification and job satisfaction. Journal of Applied Communication Research, 39(1), 38-54.

Doll, W. J., Xia, W. and Torkzadeh, G. (1994). A confirmatory factor analysis of the enduser computing satisfaction instrument. MIS Quarterly, 18(4), 453-461.

Farhoomand, A. and Drury, D. (2002). Managerial information overload. Commun. ACM, $45,127-131$.

Fornell, C. and Larcker, D. F. (1981). Evaluating structural equation models with unobservable variables and measurement error. Journal of Marketing Research, 18(1), 39-50.

Fu, S., Li, H., Liu, Y., Pirkkalainen, H. and Salo, M. (2020). Social media overload, 
exhaustion, and use discontinuance: Examining the effects of information overload, system feature overload, and social overload. Information Processing \& Management, 57(6), 102307.

Goel, A. and Gupta, L. (2020). Social media in the times of COVID-19. Journal of Clinical Rheumatology, 26(6), 220-223.

Gouws, R. H. and Tarp, S. (2016). Information overload and data overload in lexicography. International Journal of Lexicography, 30(4), 389-415.

Hair, J. F., Anderson, R. E., Tatham, R. L. and Black, W. C. (1998). Multivariate data analysis. Upper Saddle River, NJ: Prentice Hall.

Hargittai, E., Neuman, W. R. and Curry, O. (2012). Taming the information tide: Perceptions of information overload in the american home. The Information Society, 28(3), 161-173.

Holmes, R. (2020). Is COVID-19 social media's levelling up moment? Forbes. https://www.forbes.com/sites/ryanholmes/2020/04/24/is-covid-19-social-mediaslevelling-up-moment/?sh=453fb86a6c60, Erişim Tarihi: 20.12.2020.

Hoq, K. (2016). Information overload: Causes, consequences and remedies - A Study. Philosophy and Progress, 55, 49.

Karr-Wisniewski, P. and Lu, Y. (2010). When more is too much: Operationalizing technology overload and exploring its impact on knowledge worker productivity. Computers in Human Behavior, 26(5), 1061-1072.

Koeske, G. F. and Koeske, R. D. (1993). A preliminary test of a stress-strain-outcome model for reconceptualizing the burnout phenomenon. Journal of Social Service Research, 17(3-4), 107-135.

Koroleva, K., Krasnova, H. and Günther, O. (2010). “Stop spamming me!” - Exploring information overload on Facebook. 16th Americas Conference on Information Systems, August 12-15, 2010, Peru.

Laato, S., Islam, A. K. M. N., Islam, M. N. and Whelan, E. (2020). What drives unverified information sharing and cyberchondria during the COVID-19 pandemic? European Journal of Information Systems, 29(3), 288-305.

Larose, R., Connolly, R., Lee, H., Li, K. and Hales, K. (2014). Connection overload? A cross cultural study of the consequences of social media connection. Information Systems Management, 31, 59-73.

Laumer, S., Maier, C., Weitzel, T. and Wirth, J. (2016). Drivers and consequences of frustration when using social networking services: A quantitative analysis of facebook users. 22th Americas Conference on Information Systems, August 11-14, 2016, San Diego.

Lee, A. R., Son, S.-M. and Kim, K. K. (2016). Information and communication technology overload and social networking service fatigue: A stress perspective. Computers in Human Behavior, 55, 51-61.

Lee, S., Lee, S. C. and Suh, Y. (2016). Technostress from mobile communication and its impact on quality of life and productivity. Total Quality Management \& Business Excellence, 27, 1-16.

Levy, D. M. (2009). Information overload. K.E. Himma and H.T. Tavani (Ed.), The handbook of information and computer ethics (p. 497-515). New York: Wiley. 
Maier, C, Laumer, S., Eckhardt, A. and Weitzel, T. (2012). When social networking turns to social overload: Explaining the stress, emotional exhaustion, and quitting behavior from social network sites' users. ECIS 2012 - 20th European Conference on Information Systems, 10-13 June, 2013, Barcelona.

Maier, Christian, Laumer, S. and Weinert, C. (2013). The negative side of ICT-enabled communication: the case of social interaction overload in online social networks. ECIS 2013 - 21th European Conference on Information Systems, 6-8 June, 2013 Utrecht.

McCarthy, D. and Saegert, S. (1978). Residential density, social overload, and social withdrawal. Human Ecology, 6(3), 253-272.

Meyer, J. A. (1998). Information overload in marketing management. Marketing Intelligence \& Planning, 16(3), 200-209.

Misra, S. and Stokols, D. (2012). Psychological and health outcomes of perceived information overload. Environment and Behavior, 44, 737-759.

Nabity-Grover, T., Cheung, C. and Thatcher, J. (2020). Inside out and outside in: How the COVID-19 pandemic affects self-disclosure on social media. International Journal of Information Management, 55, 102188.

Nawaz, M. A., Shah, Z., Nawaz, A., Asmi, F., Hassan, Z. and Raza, J. (2018). Overload and exhaustion: Classifying SNS discontinuance intentions. Cogent Psychology, $5(1), 1515584$.

Nematzadeh, A., Ciampaglia, G. L., Ahn, Y.-Y. and Flammini, A. (2019). Information overload in group communication: from conversation to cacophony in the Twitch chat. Royal Society Open Science, 6(10), 191412.

Ragu-Nathan, T. S., Tarafdar, M., Ragu-Nathan, B. S. and Tu, Q. (2008). The consequences of technostress for end users in organizations: Conceptual development and empirical validation. Information Systems Research, 19(4), 417433.

Rainie, L., Smith, A. and Duggan, M. (2013). Coming and going on Facebook. Pew Research Centers Internet and American Life Project.

Rathore, F. and Farooq, F. (2020). Information overload and infodemic in the COVID-19 pandemic. Journal of the Pakistan Medical Association, 70, 162.

Ravindran, T., Yeow Kuan, A. C. and Hoe Lian, D. G. (2014). Antecedents and effects of social network fatigue. Journal of the Association for Information Science and Technology, 65(11), 2306-2320.

Roetzel, P. G. (2019). Information overload in the information age: a review of the literature from business administration, business psychology, and related disciplines with a bibliometric approach and framework development. Business Research, 12(2), 479-522.

Saegert, S. (1973). Crowding: Cognitive overload and behavioral constraint. Environmental Design Research, 2.

Shin, J. and Shin, M. (2016). To be connected or not to be connected? Mobile messenger overload, fatigue, and mobile shunning. Cyberpsychology, Behavior and Social Networking, 19(10), 579-586.

Shokouhyar, S., Siadat, S. and Razavi, M. (2018). How social influence and personality 
affect users' social network fatigue and discontinuance behavior. Aslib Journal of Information Management, 70.

Song, H., Jung, J. and Kim, Y. (2017). Perceived news overload and its cognitive and attitudinal consequences for news usage in South Korea. Journalism \& Mass Communication Quarterly, 94(4), 1172-1190.

Tarafdar, M., Maier, C., Laumer, S. and Weitzel, T. (2020). Explaining the link between technostress and technology addiction for social networking sites: A study of distraction as a coping behavior. Information Systems Journal, 30(1), 96-124.

Waddington, P. (1997). Dying for information? A report on the effects of information overload in the UK and worldwide. British Library Research and Innovation Report, 49-52.

Xu, Y., Yang, Y., Cheng, Z. and Lim, J. (2014). Retaining and attracting users in social networking services: An empirical investigation of cyber migration. The Journal of Strategic Information Systems, 23(3), 239-253.

Zhang, S., Zhao, L., Lu, Y. and Yang, J. (2016). Do you get tired of socializing? An empirical explanation of discontinuous usage behaviour in social network services. Information \& Management, 53(7), 904-914. 


\section{APPENDIX}

\section{English Form of Questionnaire ${ }^{1}$}

\section{Information overload}

Information overload 1 (Inf1): I am often distracted by the excessive amount of information on social media

Information overload 2 (Inf2): I feel overwhelmed by the amount of information I have been exposed to on social media

Information overload 3 (Inf3): There's more information about my friends on social media than I can follow

\section{Communication overload}

Communication overload 1 (Com1): I receive too many messages from friends through social media

Communication overload 3 (Com3): I receive too many notifications from social media as I perform other tasks

Communication overload 4 (Com4): I often feel overloaded with social media communication

Communication overload 5 (Com5): I receive more posts from my friends on social media than I can follow

\section{Social overload}

Social overload 1 (Soc1): I take too much care of my friends' well-being on social media

Social overload 2 (Soc2): I deal too much with my friends' problems on social media

Social overload 3 (Soc3): I want my friends to have fun on social media

Social overload 4 (Soc4): I care about my friends on social media

Social overload 5 (Soc5): I pay attention to posts of my friends on social media

\section{Network fatigue}

Network fatigue 1 (Fat1): Sometimes I feel bored when using social media

Network fatigue 2 (Fat2): Sometimes I feel tired when using social media

Network fatigue 3 (Fat3): Sometimes I feel drained when using social media

Network fatigue 5 (Fat5): Sometimes I feel disinterested in things on social media

\section{Discontinuous intention}

Discontinuous intention 1 (Di1): I plan to reduce my use of social media in the future

Discontinuous intention 2 (Di2): I want to reduce my use of social media in the future

Discontinuous intention 3 (Di3): I hope that I will reduce my use of social media in the future

Regret 1 (Reg1): I feel sorry for using social media frequently

Regret 2 (Reg2): I regret using social media excessively

\footnotetext{
${ }^{1}$ It includes the final factors and items used in the analysis. The discontinuous intention factor has been distributed along with the regret factor in factor analyses. Discarded items are not included. Abbreviations in parentheses are abbreviations in the tables.
} 